\title{
PENERAPAN AKUNTANSI LINGKUNGAN TERHADAP BIAYA OPERASIONAL PENGELOLAAN LIMBAH PADA RSUD PROF. DR. M.A. HANAFIAH SM BATUSANGKAR
}

\author{
THE APPLICATION OF ENVIRONMENTAL ACCOUNTING ON \\ OPERATIONAL COST OF WASTE MANAGEMENT AT PROF. DR. M.A. \\ HANAFIAH SM HOSPITAL BATUSANGKAR
}

\author{
Elfina Yenti, Revi Candra,dan Rahmi Asmara Juliati \\ Fakultas Ekonomi dan Bisnis Islam IAIN Batusangkar \\ Jl. Sudirman No. 137, Kuburajo, Lima Kaum, Batusangkar \\ elfinayenti@iainbatusangkar.ac.id, revicandra@iainbatusangkar.ac.id, rahmiasmarajuliati@gmail.com
}

Naskah diterima 20 Mei 2020, di-review 03 Juni 2020, disetujui 30 Juni 2020

\begin{abstract}
This research aims to find out the application of environmental accounting to the emerging operational costs for waste management at Prof. RSUD. Dr. MA Hanafiah SM Hospital, Batusangkar. This research design was a qualitative descriptive by using Interview and documents as the techniques of collecting data. Then it was analyzed qualitatively by conducting several procedures like collecting data (documents, archives, and interview results), identifying environmental costs, proposing environmental costs budget, and writing the report of environmental costs. The results showed Prof. Dr. MA Hanafiah SM Hospital has not applied environmental accounting on its waste management. Although the hospital has good waste management, it is suggested to apply environmental accounting since it will be a reference at managing environmental costs, reporting specific and precise environmental costs, charging more accurate costs, and minimizing environmental costs.
\end{abstract}

Keywords: Environmental Accounting, Operational Costs, Waste Management.

\begin{abstract}
Abstrak: Penelitian ini bertujuan untuk mengetahui penerapan akuntansi lingkungan terhadap biaya operasional yang muncul untuk pengelolaan limbah pada RSUD Prof. Dr. MA Hanafiah SM Batusangkar. Penelitian ini menggunakan pendekatan deskriptif kualitatif. Teknik pengumpulan data melalui dokumentasi dan wawancara. Analisis data dalam penelitian ini menggunakan metode deskriptif kualitatif. Dengan cara mengumpulkan data berupa dokumen, arsip dan hasil wawancara atau observasi, kemudian mengidentifikasi biaya lingkungan. Membuatkan usulan tentang anggaran biaya lingkungan dan kemudian membuatkan laporan biaya lingkungannya. Hasil penenlitian mendapatkan bahwa pada RSUD Prof. Dr. MA Hanafiah SM Batusangkar sudah mengelola limbahnya dengan baik, tetapi belum menerapkan akuntansi lingkungan. Selama ini semua biaya yang terkait dengan lingkungan atau limbahnya hanya dimasukkan kedalam biaya operasional. Dengan menerapkan akuntansi lingkungan pada RSUD Prof. Dr. MA Hanafiah SM Batusangkar diharapkan dapat menjadi rujukan pada pengelolaan biaya lingkungan dan pelaporan biaya lingkungan secara spesifik dan benar, pembebanan biaya yang lebih akurat, meminimalisir biaya lingkungan.
\end{abstract}

Kata Kunci: Akuntansi Lingkungan, Biaya Operasional Pengelolaan Limbah

\section{PENDAHULUAN}

Kerusakan lingkungan hidup ditandai menyebabkan gejala alam yang tidak menentu, seperti musim yang tidak sesuai dengan siklusnya, temperature cuacayang tidak normal, dan bencana yang terjadi disetiap wilayah, tercemarnya air bersih dan lain sebagainya. Kondisi tersebut merupakan isu yang terus menerus menjadi 
sorotan dunia internasional. lingkungan hidup menurut Undang-undang Nomor 32 tahun 2009 pasal (1) adalah semua benda, daya, keadaan dan makhluk hidup, termasuk manusia dan perilakunya, dalam kesatuan ruang yang mempengaruhi lingkungan alam disekitarnya, kesejahteraan, dan keberlangsungan kehidupan manusia dan makhluk hidup lain.

Undang-Undang tersebut juga menyatakan bahwa limbah merupakan residu bahan yang digunakan selama dari proses produksi atau melakukan suatu kegiatan pelayanan yang dilakukan oleh suatu entitas (Rumah tangga, Industry Pengolahan, Pertambangan, Rumah Sakit dan lain sebagainya).

Terdapat juga dalam UU No. 32 Tahun 2009 menjelaskan tentang Limbah Bahan Berbahaya dan Beracun (Limbah B3) limbah tersebut merupakan limbah yang memerlukan penangan khusus seperti gas dan debu, cair atau padat.

Rumah sakit sebagai pusat rehabilitasi kesahatan masyarakat menghasilkan limbah B3 yang dapat mempengaruhi kesehatan manusia, memperburuk kelestarian lingkungan hidup, karena limbah tersebut mempunyai karakteristik infeksius dan cenderung mengandung bahan radio aktif, berdasarkan fakta tersebut, limbah tersebut harus ditangani dengan baik oleh ahlinya dalam pengelolaannya.

Limbah rumah sakit merupakan limbah dari kegiatan operasional rumah sakit yang mengandung mikro organisme bersifat infeksius, beracun dan radiasi radio aktif, bentuk limbah tersebut berupa limbah keras (padat), cair, pasta (gel) dan gas (Pruss. Dkk.4:2005).
Limbah operasional rumah sakit dalam pengelolaannya dilakukan secara melaui sistematika sesuai dengan SOP yang sudah ditentukan, dan melalui proses khusus serta membutuhkan pengalokasian biaya yang besar, oleh karena itu rumah sakit/ perusahaan melakukan pencatatan dan pelaporan secara khusus terhadap biaya operasional pengelolaan limbahpada pencatatan dan pelaporan keuangan rumah sakit atau perusahaan. Tujuan dari pengelolaan limbah tersebut adalah bentuk tanggung jawab dan control terhadap lingkungan eksternal operasi rumah sakit (Islamey, Juli, 2016: 2).

Akuntansi lingkungan menurut Ikhsan (2009:16) merupakan sub bagian dari akuntansi social yang didalamnya terdapat akuntansi keprilakuan, akuntansi lingkungan digunakan untuk assessment dan disclosur biaya yang muncul akibat dari dampak kegiatan produksi dan pelayanan terhadap kodisi lingkungan melalui pelaporan terhadap biaya yang timbul terhadap produksi yang berdampak terhadap lingkungan dalam praktek akuntansi perusahaan atau lembaga pemerintah.

Idealnya biaya lingkungan dilaporkan secara terpisah dengan menyusun laporan biaya lingkungan secara khusus, merujuk kepada klasifikasi biayanya. Tujuan laporan biaya lingkungan adalah sebagai alat evaluasi kinerja operasional rumah sakit atau perusahaan, begitupun halnya dalam rumah sakit, rumah sakit seharusnya menydiakan rekening biaya khusus pengelolaan limbah dalam laporan, dengan tujuan untuk meyakinkan stakeholder tentang kepedulian suatu entitas terhadap lingkungan eksternal perusahaan (Hansen dan Mowen, 2009). 


\section{KERANGKA KONSEPTUAL}

\section{Akuntansi Lingkungan}

Akuntansi lingkungan merupakan sub cabang akuntansi sosial mempunyai penafsiran dan kegunaan yang berbeda-beda. Akuntansi lingkungan dapat menjadi komponen pendukung akuntansi pendapatan, akuntansi keuangan, dan akuntansi manajerial. Fokus utama akuntansi lingkungan adalah menjadi media penyampaian informasi manajerial sebagai bahan pertimbangan pengambilan keputusan manajemen melalui penerapan akuntasi lingkungan.

Akuntansi lingkungan berfungsi sebagai alat deteksi terhadap dampak lingkungan (pencegahan, pengurangan dan atau penghindaran), melalui kegiatan-kegiatan perbaikan kembali dampak lingkungan dapat menimbulkan bencana. Arti luas, akuntansi lingkungan menjadi alat komunikasi antara manager dengan stakeholders baik di dalam maupun di luar organisasi terhadap pencapaian informasi lingkungan internal dan eksternal bisnis. (Ikhsan, 2008:13-15).

\section{Tujuan Penerapan Akuntansi Lingkungan}

Ikhsan (2009: 21) menyatakan tujuan akuntansi lingkungan adalah untuk memberikan informasi bernilai informatif yang dapat memberikan perbedaan dalam pengambilan keputusan manajemen dan stakeholder. Selain itu, tujuan lainnya adalah bentuk partisipasidalam usaha konservasi terhadap lingkungan oleh perusahaan/organisasi lainya (organisasi public).

Pengembangan akuntansi lingkungan mempunyai maksud dan tujuan berikut (Ikhsan, 2009: 21):
1. Sebagai instrument managerial environment.

2. Sebagai instrumen komunikasi antara perusahaan dengan masyarakat.

\section{Pentingnya Akuntansi Lingkungan}

Akuntansi lingkungan adalah bagian akuntansi atau sub akuntansi, sehingga akuntansi lingkungan menjadi mata rantai informasi keuangan perusahaan yang relevan dan reliabel. Disamping itu, akuntansi lingkungan adalah bidang akuntansi yang mengalami perkembangan signifikan dalam proses menemukan biaya, mengukur biaya yang sudah ditemukan dan mengkomunikasikan biaya-biaya yang sudah ditemukan saat ini pada perusahaan serta menganalisis dampak lingkungan yang berpotensi akan terjadi dimasa akan datang (Ikhsan,2009: 24-26).

\section{Fungsi Dan Peran Akuntansi Lingkungan}

Fungsi dan peran akuntansi lingkungan pada entitas (usaha dan organisasi pemerintah) menurut Ikhsan (2008:15) adalah sebagai berikut:

1. Fungsi Internal

Faktorutamayang berperan padafungsi internal dalah pemimpina perusahaan. Fungsi internal yang melekat pada fungsi manajerial manager, fungsi tersebut memberikan kewenangan kepada manajemen yang bertanggung jawab untuk mengelola biaya yang muncul akibat konservasi lingkungan yang dilakukan, dan menganalisa setiap biayai yang muncul dari kegiatan konservasi lingkungan tersebut dengan tujuan menciptakan aefektiffitas dan efisiensi serta selaras dan relevan dengan pengambilan keputusan. Ekspektasi terhadap 
akuntansi lingkungan yang diharapkan adalah untuk menjadikan akuntansi lingkungan menjadi instrument manajen bisnis yang menghubungkannya dengan unit-unit bisnis lainnya.

2. Fungsi Eksternal

Fungsi eksternal adalah fungsi berhubungan erat stakeholder yang menggunakan laporan keuangan, focus utama fungsi ini adalah laporan biaya lingkungan pada pelaporan keuangan. proses yang penting untuk perusahaan perhatikan adalah pengungkapan dalam bentuk data akuntansi hasil kegiatan konservasi lingkungan. Sehingga Informasi yang diungkapkan dapat diukur secara kuantitatif, seperti informasi mengenai posisi keuangan perusahaan.

\section{Sifat Dasar Akuntansi Lingkungan}

Karakteristik utama akuntansi lingkungan menurut Ikhsan (2008: 25-33) adalah sebagai berikut:

1. Relevan (Relevance)

2. Dapat dipercaya (Reliability)

3. Materialitas (Materiality)

\section{Pengertian Biaya Lingkungan}

Biaya lingkungan menurut Ikhsan (2009:82) adalah pengorbanan ekonomis perusahaan dengan ukuran satuan moneter dari kegiatan operasional entitas (perusahaan) dan berdampak kepada kualitas lingkungan internal dan eksternal perusahaan. Biaya lingkungan menjadi penting untuk meningkatkan efektifitas dan efisiensi biayabiaya, termasuk didalamnya biaya lingkungan biaya lingkungan juga mempengaruhi biaya lain dalam proses produksi dan factor pendukung dalam pengambilan keputusan manajemen yang lebih baik, meningkatkan pendapatan dan memperbaiki kinerja perusahaan.

Biaya lingkungan dibagi kedalam biaya internal dan biaya eksternal, biaya-biaya tersebut tekait dengan biaya-biayayang terjadi dalam hubunganmya dengan kerusakan lingkungan dan perlindungan terhadap lingkungan. Biaya perlindungan lingkungan terdiri dari biaya preventif, biaya penjualan, biaya perencanaan, biaya pengendalian, pengalihan aksi dan perbaikan kerusakan yang dapat terjadi pada perusahaan dan berpengaruh pada pemerintah atau orang-orang, (Ikhsan, 2009: 103-105).

\section{METODE PENELITIAN}

Pendekatan deskrifptif kualitatif adalah pendekatan yang digunakan pada penelitian ini. Tujuan dari penelitian ini untuk mendapatan informasi mengenai pengelolaan dan aplikasi akuntansi lingkungan di rumah sakit Prof. Dr. MA. Hanafiah SM Batusangkar.

Tempat penelitisn ini adalah RSUD Prof. Dr. MA. Hanafiah SM Batusangkar. Objek penelitian adalah kegiatan pengelolaan limbah pada RSUD Prof. Dr. MA. Hanafiah SM Batusangkar dan pelaporan biaya lingkungan RSUD Prof. Dr. MA. Hanafiah SM Batusangkar dalam pengelolaan limbah.

Data penelitian yang diperoleh, diperoleh melalui cara sebagai berikut:

1. Dokumentasi

Proses menghimpun dokumen anggaran dan realisasi anggaran yang diperoleh dari RSUD Prof. Dr. MA. Hanafiah SM Batusangkar. 
2. Wawancara

Wawancara adalah proses pencarian informasi melalui tanya-jawab tatap muka dengan pihakpihak yang dapat memberikan informasi dan data penelitian untuk memperoleh komprehensif(relevan dan reliable), (Sugiyono, 2018:224).

Data penelitian yang telah dikumpulkan dan direduksi dianalisis dengan pendekatan deskriptif kualitatif, pendekatan dskriftif kualitatif digunakan untuk mengamati status sekelompok manusia, suatu objek, peristiwa pada masa sekarang (Ingguoe, 2015: 8).

Langkah-langkah analisis data yang dilakukan peneliti dalam penelitian ini adalah sebagai berikut:

1. Pengumpulan data penelitian tang dibutuhkan, melalui obseravsi, wawancara, dan dokumentasi berupa arsip dan hasil wawancara, kemudian data yang diperoleh diseleksi serta diklasifikasi berdasarkan kebutuhan penelitian untuk menjawab rumusan masalah.

2. Pengidentifikasian biaya lingkungan, proses ini dimulai dengan menemukan instrument biaya lingkungan yang muncul dan tercatat pada laporan keuangan, karena dalam laporan keuangan tidak semua biaya yang tercatat adalah biaya lingkungan. Penulis berpedoman kepada dokumen anggaran Perubahan BLUD tahun 2019.

3. Membuat usulan tentang laporan biaya lingkungan, usulan ini diajukan penulis karena rumah sakitsebagai pusat rehabilitasi kesehatan dalam aktivitasnya menghasilkan limbah yang rentan terhadap lingkungan. Ada lima usulan untuk membuata laporan biaya lingkungan yaitu: prevention costs, deteksion costs, internal failure costs dan external failure cost.

4. Penyusunan laporan akuntansi lingkungan berdasarkan teori Hansen dan Mowen.

5. Analisis pelaksanaan tanggung jawab lingkungan oleh RSUD Prof. Dr. MA. Hanafiah SM Batusangkar terkait dengan pengelolaan limbah. Rumah sakit tugasnya memberikan pelayanan kesehatan yang menghasilkan limbah infeksius bertanggung jawab penuh terhadap pengelolaan limbah berdasarkan UU Nomor 23 Tahun 2009.

6. Konklusi.

Konklusi yang ditarik berdasarkan proses pengumpulan data yang komprehensif (relevan dan reliable). Berdasarkan temuan peneliti, peneliti membuat kesimpulan tentang pengelolaan limbah dan perlakuan akuntansi lingkungan biaya operasional pengelolaan limbah RSUD Prof. Dr. MA. Hanafiah SM Batusangkar.

\section{PEMBAHASAN DAN HASIL}

\section{Pengidentifikasian Biaya Lingkungan}

RSUD Prof. Dr. MA. Hanafiah SM Batusangkar belum menerapkan akuntansi lingkungan. Selama ini biaya pengelolaan limbah tersebut hanya di masukkan kedalam biaya operasional rumah sakit saja. Maka dari itu tidak ada pencatatan khusus yang membahas tentang biaya pengelolaan limbah pada RSUD Prof. Dr. MA. Hanafiah SM Batusangkar ini.

Elemen biaya lingkungan dalam laporan keuangan dipisahkan merujuk kepada empat kategori aktivitas yaitu pencegahan, pendeteksian, kegagalan internal dan kegagalan eksternal 


\section{Biaya Pencegahan (Prevention Cost)}

Preventif cost adalah pengorbanan ekonomi untuk kegiatan pencegahan produksi limbah dan/ atau sampah yang dapat menyebabkan kerusakan lingkungan pada RSUD Prof. Dr. MA. Hanafiah SM Batusangkar ada beberapa biaya yang dapat dikelompokan sebagai biaya pencegahan antara lain:

1) Pembangunan Workshop IPS-RS

Workshop khusus yang di gunakan oleh pekerja untuk mendaur ulang sampahsampah yang masih bisa di perbaiki seperti sarana dan prasarana rumah sakit yang rusak yang masih bisa diperbaiki. Besaran biaya yang di gunakan dalam pembangunan workshop IPS-RS ini yaitu Rp. 65.000.000

2) Pengadaan Alat-Alat Workshop IPS_RS

Pengadaan alat-alat workshop IPS_RS di gunakan untuk memperbaiki sarana dan prasarana yang rusak, alat-alat workshop dapat berupa alat-alat bangunan, alatalat listrik, alat-alat perpipaan (untuk memperbaiki aliran air) dan lain sebagainya. Untuk pengadaan alat-alat workshop ini memerlukan biaya sebesar Rp. 50.000.000.

3) Pembangunan Bak Equalisali IPAL

Bak equalisasi IPAL yaitu bak-bak yang digunakan untuk menampung air limbah cair rumah sakit dan kemudian di tampung pada tangka clorin kemudian dialirkan ke bak equalisasi yang sudah diberi bakteri, pembangunan bak-bak equalisasi tersebut sangat dibutuhkan karena jika bak equalisasinya tidak memadai maka akan berpengaruh pada kualitas air yang dihasilkan. Untuk membangun Bak Equalisasi IPAL ini penganggaran biayanya di anggarkan pada biaya sebelum perubahan yaitu sebesar Rp. 46.000.000.

4) Pengadaan Mesin Laundry

Mesin laundry digunakan untuk membersihkan pakaian- pakaian dokter atau kain-kain yang disediakan oleh pihak rumah sakit yang dipakai oleh pasien. Dengan adanya mesin laundry ini juga akan mengalirkan limbah yang langsung dialirkan pada IPAL. Untuk pengadaan mesin laundry ini pihak rumah sakit mengeluarkan biaya sebesar Rp. 250.000.000.

\section{Biaya Deteksi Lingkungan}

Biaya deteksi lingkungan adalah pengorbanan ekonomi untuk kegiatan deteksi penerapan standar lingkungan telah memenuhi atau belum terhadap produk, proses dan aktivitas lainnya pada RSUD Prof. DR. MA Hanafiah SM Batusangkar, biaya deteksi yang muncul dari kegiatan ini adalah biaya untuk Jasa Uji Laboratorium.

Uji laoratorium dilakukan untuk memperoleh informasi engenai mutu air limbah dan standar aman air limbah ke lingkungan sehingga air limbah tersebut mencemari lingkungan dan membahayakan lingkungan dan masyarakat sekitar. Pengujian ini seperti uji air limbah yang dilakukan setiap awal bulan yang lansung diantar lansung ke labolatorium kesehatan daerah yang ada di kota padang. Biaya yang di butuhkan untuk uji labor ini yaitu sebesar Rp. 43.850.000. Laporan anggaran perubahan BLUD tahun 2019 menunjukan jumlah anggaran 
sebelum perubahan lebih besar dari anggaran setelah perubahan yaitu sebelum perubahan berjumlah Rp. 3.850.975.215 dan menurun setelah dilakukan perubahan menjadi Rp. 3.584.449.215.. Penurunan biaya ini sebesar Rp. 268.526.000 yang disebabkan karena adanya biaya yang di gunakan untuk pengadaan mesin laundry dan untuk membangun bak equalisasi IPAL yang setelah perubahan kedua item biaya ini tidak mengeluarkan biaya tambahan lagi.

Pembelian mesin laundry menghabiskan dana sebesar Rp. 250.000.000 dan untuk pembangunan bak equalisasi IPAL menghabiskan biaya sebesar Rp. 46.000 .000 dan tidak ada biaya tambahan lagi setelah dilakukan perubahan dikarenakan mesin laundry belum mengalami kerusakan atau penggantian suku cadangnya semenjak pertama kali di beli karena jika mesin laundry mengalami kerusakan ringan lansung di perbaiki oleh tenaga ahli yang dimiliki oleh IPS-RS.

Penurunan pada biaya jasa tenaga kebersihan/cleaning service yang sebelum perubahan menghabiskan biaya sebesar Rp. 1.884.801.000 dan setelah dilakukan perubahan mengalami penurunan menjadi Rp. 1.705.000.000

Tabel 1.Biaya Lingkungan Berdasarkan Anggaran Perubahan BLUD Tahun 2019

\begin{tabular}{|c|c|c|}
\hline \multirow{2}{*}{ Komponen biaya } & \multicolumn{2}{|c|}{ Tahun 2019} \\
\hline & Sebelum perubahan & Sesudah perubahan \\
\hline \multicolumn{3}{|l|}{ BIAYA PEMELIHARAAN } \\
\hline Biaya pemeliharaan dan pengelolaan limbah RS & Rp. 73.580 .000 & Rp. 73.580 .000 \\
\hline \multicolumn{3}{|l|}{ Biaya Pemeliharaan alat kantor } \\
\hline Pemeliharaan mesin Genset dan incenarator & Rp. 43.850.000 & Rp. 43.850 .000 \\
\hline Pemeliharaan mesin potong rumput/ suku cadang & Rp. 1.754.000 & Rp. 1.754 .000 \\
\hline \multicolumn{3}{|l|}{ BIAYA BARANG DAN JASA } \\
\hline Biaya Penyediaan Penampung Sampah (Kantong Plastik) & Rp. 50.000 .000 & Rp. 50.000 .000 \\
\hline Biaya Bahan Pembersih Dan Alat Kebersihan & Rp. 137.700.000 & Rp. 137.700 .000 \\
\hline \multicolumn{3}{|l|}{ Biaya Langganan Listrik } \\
\hline IPAL & Rp. 106.920 .000 & Rp. 106.920.000 \\
\hline Coolstorage & Rp. 4.665 .600 & Rp. 4.665 .600 \\
\hline Nayati & Rp. 21.772 .800 & Rp. 21.772 .800 \\
\hline \multicolumn{3}{|l|}{ Biaya Pemeliharaan Mesin } \\
\hline BBM Mesin Potong Rumput & Rp. 3.946 .500 & Rp. 3.946.500 \\
\hline BBM Dan Pelumas & Rp. 363.955 .000 & Rp. 520.000 .000 \\
\hline \multicolumn{3}{|l|}{ Biaya Kerja Sama } \\
\hline Biaya jasa tenaga kebersih / cleaning service & Rp.1.884.801.000 & Rp. 1.705.000.000 \\
\hline Biaya Pemusnah Limbah Medis/ LB3 & Rp. 746.410 .315 & Rp. 746.410 .315 \\
\hline Jasa Uji Laboratorium (Peralatan, Air Bersih, Limbah, Penangkal Petir Dan Emisi) & Rp. 43.850 .000 & Rp. 43.850 .000 \\
\hline Biaya Retribusi Sampah & Rp. 8.770.000 & Rp. 10.000 .000 \\
\hline \multicolumn{3}{|l|}{ BIAYA PENGELUARAN INFESTASI } \\
\hline Pembangunan Workshop IPS-RS & Rp. 65.000 .000 & Rp. 65.000 .000 \\
\hline Pengadaan alat IPS-RS & - & Rp. 50.000 .000 \\
\hline Pengadaan Mesin Laundry & Rp. 250.000.000 & +1 \\
\hline Pembangunan Bak Equalisasi IPAL & Rp. 46.000.000 & - \\
\hline TOTAL BIAYA LINGKUNGAN & Rp. 3.850.975.215 & Rp. 3.584.449.215 \\
\hline TOTAL BIAYA OPERASIONAL & Rp. 60.000.000.000 & Rp. 60.000 .000 .000 \\
\hline PERSENTASE BIAYA LINGKUNGAN & $6,4216 \%$ & $5,9741 \%$ \\
\hline
\end{tabular}

Sumber: Data Diolah 


\section{Laporan Biaya Lingkungan}

Biaya lingkungan adalah biaya yang terjadi karena kualitas lingkungan yang buruk dan/atau berpotensi akan berkualitas buruk yang akan muncul dimasa akan datang akibat dari aktivitas operasional rumah sakit. Dalam laporan keuangan RSUD Prof. Dr. MA. Hanafiah SM Batusangkar, dari laporan anggaran perubahan BLUD tahun 2019, belum diungkapkan secara lengkap mengenai biaya-biaya yang terkait aktivitas lingkungannya. Mengingat aktivitas rumah sakit yang rentan terhadap pencemaran lingkungan melalui limbah yang dibuang, maka sudah seharusnya BLUD tersebut melaporkan secara khusus biaya yang berkaitan dengan pengelolaan lingkungannya. RSUD Prof. Dr. MA. Hanafiah SM Batusangkar merupakan organisasi yang bebentuk BLUD (Badan Layanan Umum Daerah). Organisasi BLUD sebagai organisasi nirlaba kepemerintahan sesuai dengan peraturan pemerintah No. 23 Tahun 2005 pasal 26 menyebutkan: "Akuntansi dan pelaporan keuangan BLUD diselenggarakan sesuai dengan standar akuntansi akuantansi yang berlaku sesuai dengan jenis layanannya dan ditetapkan oleh menteri/ pimpinan lembaga/gubernur/ bupati/ walikota sesuai dengan kewenangannya".

Berdasarkan UU tersebut, RSUD Prof. Dr. MA. Hanafiah SM Batusangkar dituntut untuk menyusun laporan biaya lingkungan demi kepentingan stakeholders, jika laporan biaya lingkungan dalam pelaporan keuangan telah diterapkan, oleh RSUD Prof. Dr. MA. Hanafiah SM Batusangkar, akan berdampak pada reputasi dan citra yang baik di kalangan stakeholder, karena dianggap peka terhadap lingkungan sekitar.

Dalam hal ini, peneliti mencoba membuat usulan tentang laporan biaya lingkungan pada RSUD Prof. Dr. MA. Hanafiah SM Batusangkar pada tahun 2019. Laporan akuntansi lingkungan yang berpedoman kepada 4 kategori biaya dalam konsep Hansan dan Mowen yaitu Prevention costs (biaya pencegahan), Detection cost (Biaya deteksi), Internal Failure Cost (Biaya kegagalan internal), dan External failure cost (Biaya kegagalan eksternal)

Tabel 2. Laporan Biaya Lingkungan RSUD Prof. Dr. MA Hanafiah SM Batusangkar Tahun 2019

\begin{tabular}{|c|c|c|c|}
\hline Biaya Lingkungan & $\mathbf{R p}$ & Total & $\begin{array}{l}\text { \% Seluruh Biaya } \\
\text { Tahun } 2019\end{array}$ \\
\hline BIAYA PENCEGAHAN & & & \multirow{6}{*}{$3,0707 \%$} \\
\hline Pembangunan Workshop IPS-RS & Rp. 65.000 .000 & & \\
\hline Pengadaan Alat Wokshop IPS-RS & Rp. 50.000 .000 & & \\
\hline Pembangunan Bak Equalisasi IPAL & $\mathrm{Rp}-$ & & \\
\hline Pengadaan Mesin Laundry & $\mathrm{Rp}-$ & & \\
\hline Total Biaya Pencegahan & & Rp. 115.000 .000 & \\
\hline \multicolumn{3}{|l|}{ BIAYA DETEKSI LINGKUNGAN } & \multirow{3}{*}{$1,1709 \%$} \\
\hline Jasa Uji Laboratorium & Rp. 43.850 .000 & & \\
\hline Total Biaya Deteksi Lingkungan & & Rp. 53.850 .000 & \\
\hline \multicolumn{3}{|l|}{ BIAYA KEGAGALAN INTERNAL } & \multirow{5}{*}{$95,7584 \%$} \\
\hline Biaya Pemeliharaan Dan Pengelolaan Limbah Rs & Rp. 73.580 .000 & & \\
\hline \multicolumn{3}{|l|}{ Biaya Pemeliharaan Alat Kantor } & \\
\hline Pemeliharaan Mesin Genset Dan Incenarator & Rp. 43.850 .000 & & \\
\hline Pemeliharaan Mesin Potong Rumput & Rp. 1.754 .000 & & \\
\hline Biaya Retribusi Sampah & Rp. 10.000 .000 & & \\
\hline
\end{tabular}




\begin{tabular}{|c|c|c|c|}
\hline Biaya Penyediaan Penampung Sampah (Kantong Plastik) & Rp. 50.000 .000 & & \\
\hline Biaya Bahan Pembersih Dan Alat Kebersihan & Rp. 137.700 .000 & & \\
\hline \multicolumn{3}{|l|}{ Biaya Bahan Bakar } & \\
\hline Bbm Mesin Potong Rumput & Rp. 3.946.500 & & \\
\hline BBM Dan Pelumas & Rp. 520.000.000 & & \\
\hline \multicolumn{3}{|l|}{ Biaya Langganan Listrik Dan Air } & \\
\hline Listrik & Rp. 133.358.400 & & \\
\hline Air' & Rp. 160.569 .050 & & \\
\hline \multicolumn{3}{|l|}{ Biaya Kerja Sama } & \\
\hline Biaya Jasa Tenaga Kebersih / Cleaning Service & Rp. 1.705 .000 .000 & & \\
\hline Biaya Pemusnah Limbah Medis/ LB 3 & Rp. 746.410.315 & & \\
\hline Total Biaya Kegagalan Internal & & Rp. 3.586.168.265 & \\
\hline BIAYA KEGAGALAN EKSTERNAL & Rp - & & \multirow[b]{2}{*}{$0 \%$} \\
\hline Total Biaya Kegagalan Eksternal & & $\mathrm{Rp}$ - & \\
\hline Total Biaya Lingkungan & & & Rp. 3.745.018.265 \\
\hline
\end{tabular}

(Sumber: Data Diolah)

Dari laporan keuangan yang telah diuraikan di atas dapat dilihat bahwa RSUD Prof. Dr. MA. Hanafiah SM Batusangkar mengeluarkan biaya lingkungan per tahun 2019 yaitu sebesar Rp. 3.745.018.265 yang di bagi menjadi:

1. Biaya Pencegahan

Pada biaya pencegahan ini biaya-biaya yang diperlukan yaitu biaya pembangunan worshop IPSRS yang berfungsi sebagai tempat untuk memperbaiki alat-alat rumah sakit yang mengalami kerusakan sebelum menjadi limbah jika masih bisa diperbaiki maka para teknisi akan memperbaikinya.

Penyelengaraan workshop ini menghabiskan biaya sebesar Rp. 65.000.000. Untukmelengkapi semua kelengkapan para teknisi dibutuhkan alat-alat untuk memperbaiki, yang disebut dengan alat-alat workshop seperti alat-alat bangunan, alat-alat listrik, alat-alat perpipaan dan lain sebagainya yang menghabiskan dana Rp. 50.000.000. Biaya pencegahan ini menghabiskan dana sebesar 3,0707\% dari seluruh total biaya lingkungan pada RSUD Prof. Dr. MA. Hanafiah SM Batusangkar.
2. Biaya Deteksi Lingkungan

Biaya deteksi lingkungan ini terdiri dari jasa uji labor yang dapat memberikan gambaran bagaimana kualitas limbah pada RSUD Prof. Dr. MA. Hanafiah SM Batusangkar yang membutuhkan biaya sebesar Rp. 43.850.000. Biaya deteksi lingkungan ini memiliki persentase yaitu $1,1709 \%$ dari total biaya limbah keseluruhan.

3. Biaya Kegagalan Internal

Biaya yang berasal dari dalam rumah sakit itu sendiri seperti yang ada pada RSUD Prof. Dr. MA. Hanafiah SM Batusangkar biaya kegagalan internalnya terdiri dari biaya pemeliharaan dan pengelolaan limbah RS, biaya pemeliharaan alat kantor, biaya penyediaan penampung sampah, biaya bahan pembersih dan alat kebersihan, biaya pengadaan APD, biaya bahan bakar dan biaya langganan listrik dan air serta biaya kerja sama dengan pihak ke 3. Total biaya kegagalan internal yaitu sebesar Rp. 3.586.168.265 Biaya kegagalan internal ini memiliki presentase yang sangat besar 
diantara biaya-biaya yang lainnya yaitu: $95,7584 \%$ dari total biaya lingkungan.

4. Biaya Kegagalan Eksternal

Khusus untuk biaya kegagalan eksternal ini belum ada. Dikarenakan belum terjadi dibuktikan dengan tidak adanya laporan dari masyarakat sekitar terkait masalah lingkungan yang terjadi di lingkungan RSUD Prof. Dr. MA. Hanafiah SM Batusangkar. Jadi belum ada biaya yang dikeluarkan untuk biaya kegagalan eksternal ini.

\section{PENUTUP}

Berdasarkan, analisis yang telah dilakukan, disimpulkan bahwa pengelolaan limbah pada RSUD Prof. Dr. MA. Hanafiah SM Batusangkar sangat baik, dibuktikan dengan sudah adanya pengelolaan IPAL yang sesuai dengan SOP, pelaksanaan uji labor secara rutin, dan pengecekan PH air rutin setiap paginya. Rumah sakitjuga sudah memiliki gudang sendiri dan TPS yang didalamnya tersedia bak penampung sampah rumah tangga dan ruangan khusus untuk menyimpanan sampah infeksius sebelum di ambil oleh pihak ke III. Juga menjalin kerjasama dengan Dinas Lingkungan Hidup dan pihak ke 3 dalam pengolahan limbah infeksius dan limbah rumah tangga.

RSUD Prof. Dr. MA. Hanafiah SM Batusangkar sampai saat ini belum mengaplikasikan akuntansi lingkungan dalam pencatatan dan pelaporannya, kenyataan ini dibuktikan dengan belum adanya laporan yang dibuatkan khusus mengenai biaya lingkungan. Selama ini biaya-biaya lingkungan pada RSUD hanya di masukkan kedalam biaya operasional.
Tujuan penenerapan akuntansi lingkungan pada RSUD Prof. Dr. MA. Hanafiah SM Batusangkar dapat memberikan manfaat seperti pengelolaan biaya lingkungan yang baik, pembebanan biaya ang lebih akurat, meminimalisir biaya lingkungan dan rumah sakit memperoleh kepercayaan yang lebih dari stakeholders.

\section{DAFTAR KEPUSTAKAAN}

Anggito Albi \& Setiawan Johan. 2018. Metode Penelitian Kualitatif. CV Jejak, Jln. Bojong Genteng Nomor 18, Kec. Bojong Genteng Kab. Sukabumi, Jawa Barat.

Anonim. 2009. Undang-Undang Nomor 32 Tahun 2009. Tentang Perlindungan Dan Pengelolaan Lingkungan Hidup. Jakarta: Sekretariat Negara

A.Pruss.2005.Pengelolaan Aman Limbah Layanan Kesehatan. Jakarta:Penerbit Buku Kedokteran EGC.

Hansen Dan Mowen. 2004. Manajemen Biaya. Edisi Bahasa Indonesia. Buku Kedua. Jakarta. Salemba Empat.

Hansen Dan Mowen. 2009. Akuntansi Manajemen. Edisi 8. Jakarta. Salemba Empat.

Ikatan Akuntansi Indonesia.Pernyataan Standar Akuntansi Keuangan No.33.Revisi 2011.

Ikhsan Arfan. 2008. Akuntansi Lingkungan Dan Pengungkapannya. Graha Ilmu Candi Gerbang Permai Blok R/6: Yogyakarta 55511. Ikhsan Arfan. 2009. Akuntansi Manajemen Lingkungan. Graha Ilmu, Candi Gerbang Permai Blok R/6: Yogyakarta 55511. 
VOLUME 4, NOMOR 1, JUNI 2020

Ingguoe, Leksi. 2015. Tata Bahasa Rote. Grup

Penerbit CV Budi Utama Anggota IKAPI 076/ DIY/2012.

Islamey Fika Erisya. 2016. Perlakuan Akuntansi Lingkungan Terhadap Pengelolaan Limbah Pada Rumah Sakit Paru Jember. Jurnal Fakultas Ekonomi Universitas Muhammadiyah, Jember: Juli.
Sugiyono. 2018. Metode Penelitian Administrasi Dilengkapi Dengan Metode R \& D. Alfabeta. CV. Jl. Gegerkalong Hilir No.84 Bandung.

Profil RSUD Prof. Dr. M. A. Hanafiah, SM Batusangkar 2018. 